\title{
Technology Literacy and Student Practice: Lecturing Critical Evaluation Skills
}

\author{
J. Julia \\ Universitas Pendidikan Indonesia \\ Bandung, Indonesia \\ I. Isrokatun \\ Universitas Pendidikan Indonesia \\ Bandung, Indonesia
}

\begin{abstract}
To conduct assignments and research projects effectively, students need to be taught the skills to maximally operate Microsoft Office tools and use the Reference Manager application to properly manage reference sources. This research aims at guiding students to be able to think critically and in evaluative manner towards their skills in using technological tools to support their academic tasks. The design of the research is action research through collaborative team work carried out through seven critical stages to evaluate students' technology literacy. The results of the action research showed that students were able to evaluate their skills in technology literacy, thus encouraging them to improve their skills to complete academic tasks, especially research projects. Hands-on practices in every act have directed the students to think critically and provide them awareness about the importance of technology and information literacy to globally explore the academic universe.
\end{abstract}

Keywords: technology literacy; critical evaluation skill; student practice; action research; Internet sources.

\section{Introduction}

In the new academic year, seventh semester students of elementary school teacher education program must prepare a proposal for their research project, yet, almost all students were confused about the research project. A quick survey showed that the students had difficulties coming up with new and interesting topics for their research project. They used bachelor's thesis research reports in the library as their starting point reference in finding research topics. As a result, the research topics they offered only followed the footsteps of previous reports on the same topic with only the research samples being different. This meant their research projects were not state-of-the-art due to the lack of ability to carry 
out a literature review. Meanwhile, a comprehensive literature review of stateof-the-art papers is vital to the framework of the past, and to shed light on future directions (Özceylan et al., 2018). In addition, from examining student research report files, the majority of students did not use quality reference sources. Their reference sources were local books, and unfortunately, journals were rarely used. Furthermore, all students did not use the reference manager to manage citations. What is more concerning, in writing their report, the students did not use the features available on Microsoft Office Word application, such as Heading and Caption, hence they made the list of tables, images, contents manually.

All of these insights raised the following questions: Why did the students only use local libraries as a starting point for conducting research? Did they know any quality resources for high-quality research in the Internet? Why did they not use Microsoft Office tools to facilitate the preparation of research reports? These questions lead to the following question: Do students have good knowledge and skills in technology literacy? This phenomenon was also observed in colleagues at work. Therefore, this action research was conducted to answer the questions above. The aim was to help students become aware of the skills in technology that they had ignored. Students were led to be able to evaluate the skills in technological literacy that they were missing.

In the conceptual framework, the students must be technology literate in order to be able to do assignments, such as making papers or research projects properly. Being technology literate implies to have the erudition and skill to use computers and linked technologies competently (Congress, 1984; Quinn \& Fitch, 2014). Two basic life skills basic that students need to master in the technology era are computer literacy (Klassen, 1983; Randhawa \& Hunt, 1984; Robinson \& Thoms, 2001) including the mastery of productivity tool software such as Microsoft Office tools (Heath \& Bell, 2006; John H. Heinrichs \& Lim, 2009), and information literacy (Heil, 2005; Mackey \& Jacobson, 2005).

Computer literacy is one of the most vital 21st century competences (Bayrak \& Yurdugül, 2013). Reinoehl and Hanna (1990) define computer literacy as computer skill, in connection to skill in an expert or educational area. A person can be measured as computer literate if $\mathrm{s} /$ he has knowledge about computer, $\mathrm{s} /$ he recognizes how it operates and if $\mathrm{s} / \mathrm{he}$ is capable to use and employ a computer (Rochester \& Rochester, 1991). In other words, someone who is computer literate is a person who has the skill to utilize computer for information recovery, interaction and problem solving by controlling computer and applications in order to reach some goals (Akkoyunlu \& Orhan, 2003). One crucial aspect and an important part of computer literacy is mastery of software. Expertise in software productivity tools was the most significant capability for the students to own (McCoy, 2002). Therefore, in this research, computer literacy is viewed as a set of abilities for students to work on research projects using computer devices, including in operating various applications supporting research projects. 
Information literacy is defined as a set of capabilities that require individuals to recognize when information is needed and have the ability to find, evaluate, and effectively use the information needed (Gullikson, 2006; Iannuzzi, 2000). Information literacy and computer skills can be measured as a merged evaluation containing five essential skills: basic computers, advanced computers, Internet, research, and presentations (John H. Heinrichs \& Lim, 2009; Pask \& Saunders, 2004). One important part of information literacy is the ability to critically evaluate internet sources and decide whether each source is unbiased, accurate, and written by qualified people who have specific knowledge about the topic (Heil, 2005). In line with the American Library Association, the information literate student evaluates information and its sources critically and incorporates selected information into his or her knowledge base and value (ALA, 2005). However, students often ignore this aspect and use internet resources carelessly without knowing and tracing their credibility. Thus, students need to be guided so that they are able to use quality resources from the Internet.

Results of previous research (John H. Heinrichs \& Lim, 2009) about a survey concerning supposed functional skills and abilities in word-processing and presentation equipment, showed the highpoint of the requirement to impartapplication productivity software appliances and the cooperation ability into the higher education academic program to improve information literacy. Analysis of variance and regression analysis were used to analyze the mean differences between two information areas and the elements of felt and wanted abilities. These results indicated that the current information science literature identifies the crucial of information technology to accomplish information literacy.

Kankam (2017) explored how students evaluate online-based information source. The researcher viewed that the Internet obviously gives the prospect for students to increase their knowledge quickly because they can access large amounts of information from various sites. However, retrieving information from the Internet also has its disadvantage since not all material is of high quality. This research showed that most of the high school students did several types of assessment of online material sources, yet they did not implement the correct criteria. The research also revealed that the students were not familiarized to the assessment criteria at school and this had donated to the disparities in their evaluation abilities.

Auberry (2018) showed that digital citizens can easily retrieve content. Therefore, they require direction in perceiving what to do with the materials that they obtain. The skills to explore an author's proficiency, to observe a source's reliability over time, and to validate truths from several places are all abilities that advantage from learning with directed practice. This research showed that education and hands-on practice were the best hope for students to become ethical content creators. In other words, appropriate guidance and direction were needed by students to become part of the digital and information literacy community. 
A current research on ICT literacy was conducted by SANTOS et al. (2019) in Portugal by involving students of elementary education and secondary education as the samples. Their research focused on determining the relationship between internet literacy, computer literacy, and information literacy with the support from parents and teachers. This research revealed that the use of internet as pedagogical tool is the main factor influencing school performance and ICT literacy was found to be positively influenced by parents and teachers' support.

In response to the previous studies, this action research is focused on literacy technology student, where they were guided to have the ability to be criticalevaluative towards literacy skills and information technology, both in the use of Microsoft Office tools and use reference sources from the Internet. This research was conducted by designing a number of critical steps supported by collaborative work.

\section{Method}

In order to enhance evaluative skills of students' technology literacy, an appropriate model must be chosen, and we believe that action research is the best method to choose. In addition to its reflective character, action research can assist the sustainable steps or treatments based on the needs that have to be developed. In the context of this research, the needs are seen from the perspective of students and researchers. Following are detailed research design, research site, and research subjects.

\subsection{Research Design and Collaborative Aspects}

This research employs action research design with the aim of exploring practical problems with the intention of developing a solution to the problem (Creswell, 2015). Collaboration with various parties is one of the keys to the continuity of this action research. Therefore, this research involved some colleagues to collaborate. Collaboration is an important factor especially when carrying out action research (Creswell, 2015; Jaipal \& Figg, 2011; Leeman et al., 2018). The easiest way to start collaboration is to publish what is needed by the project and see if anyone is interested (Heil, 2005). In the seventh semester, many lecturers from various departments at the university have to guide students to carry out research projects. This opportunity was used as well as possible to offer this task to them. Some colleagues were interested in participating in this action research. They cited the same problems associated with the technology literacy of students, the problems even occurred until the students made the final paper. Therefore, the colleagues shared their views that this issue should be anticipated immediately.

The topics for the action research material for students of the seventh semester were specifically discussed. The seventh semester students are assumed to already have qualified knowledge and skills in technology literacy. The results of the discussion narrowed to topics of technology literacy that are relevant and urgent to be mastered by students of the seventh semester such as how to find references from reputable sources, how to manage references using the reference manager, and how to prepare a research report by using Microsoft Office tools 
properly and effectively. It was agreed that the results of the student research project had to meet the set requirements. One of the requirements set by the collaboration team was that the results of student research projects had to be published internationally and indexed in a reputable indexer or at least in a national journal. Therefore, the collaboration team immediately prepared the steps to be taken during the action research.

\subsection{Research Location and Subjects}

This research involved students from the university is located in the center between several regencies bordered by the coastal area and the capital of West Java in Indonesia. The regency where the university was established is a region in which the majority of the people are rice farmers. The university is a highly reputable educational institution; hence, students from surrounding regencies choose this university as a priority to apply to, even though in their own area a university of education has been established. Of all seventh semester students, a class in the elementary school teacher education program concentrating on arts, who were going to carry out art research projects, $(n=13,100 \%)$ participated in this research. The class consisted of five (38.46\%) male students and eight $(61.54 \%)$ female students. They were between 21-22 years old. Ten students were from the same regency and three students came from other regencies. All of them agreed to participate in this action research, which was conducted in one semester.

\section{Results}

The critical steps taken to generate students' critical and evaluative of thinking on technology literacy was done by conducting several planned and structured processes. These processes involve data collection, pre-action analysis, sevenstages action, and post-action analysis. Following are detailed elaboration of the processes.

\subsection{Description of Pre-Action Data Collection and Analysis}

First, the students filled out a pre-action survey that represented their knowledge and skills in using and choosing reference sources, using reference managers, and using Microsoft Office tools that could facilitate the preparation of research project reports and assignments. Table 1 provides a list of student statements about the use of computers, Microsoft Office Word, Reference Manager, and offline and online references. Responses to the use of applications and reference sources indicated that $100 \%$ of students used computers/laptops and Microsoft Office Word application to do assignments. However, 69.23\% of the students did not use Microsoft Office tools, and $61.54 \%$ did not use the Reference Manager application. Some students who were not used to Microsoft Office tools and Reference Manager were interviewed further to identify their understanding of the use of applications and reference sources. We asked, "Why you do not use Microsoft Office tools and Reference Manager in doing assignments?" Students responded that they had not known the functions of these tools. Other students answered that they had not known that those tools existed in Microsoft Office Word. 
Table 1. Use of Application and Reference Source

\begin{tabular}{llll}
\hline Use of Application & Yes & No \\
\hline Do you use a computer or laptop to do course assignments? & 13 & \\
\hline $\begin{array}{l}\text { Do you use the Microsoft Office Word application to do course } \\
\text { assignments? }\end{array}$ & 13 & \\
\hline $\begin{array}{l}\text { Do you use the Heading, Caption, and Citation menus in Microsoft } \\
\text { Office Word? }\end{array}$ & 4 & 9 \\
\hline $\begin{array}{l}\text { Do you use the Reference Manager application to manage and use } \\
\text { citation in writing a paper? }\end{array}$ & 5 & 8 \\
\hline
\end{tabular}

\begin{tabular}{llll}
\hline Offline Reference Source & Book & Journal & $\begin{array}{l}\text { Bachelor's } \\
\text { Thesis }\end{array}$ \\
\hline $\begin{array}{l}\text { In doing a research project, what kind of source do you } \\
\text { refer to firstly? }\end{array}$ & 8 & 5 & \\
\hline $\begin{array}{l}\text { What is your main reference source in doing a research } \\
\text { project? }\end{array}$ & 7 & 5 & 1 \\
\hline Online Reference Source & Yes & No & $\begin{array}{l}\text { I don't } \\
\text { know }\end{array}$ \\
\hline Do you use reference sources available in the Internet? & 11 & 1 & 1 \\
\hline $\begin{array}{l}\text { Do you identify the quality of the references obtained } \\
\text { from the Internet? }\end{array}$ & 7 & 3 & 3 \\
\hline Do you browse for sites of quality reference sources? & 2 & 3 & 8 \\
\hline $\begin{array}{l}\text { Do you make use of the online reference sources } \\
\text { subscribed by the university? }\end{array}$ & 4 & 2 & 7 \\
\hline
\end{tabular}

The survey results showed that $53.85 \%$ of students prioritized using books as the main reference source followed by journals $(n=5,38.46 \%)$, and bachelor's thesis $(n=1,7.69 \%)$. Meanwhile, for online reference sources, the survey results showed that $84.62 \%$ students used reference resources available on the Internet. Most students $(n=7,53.85 \%)$ admitted that they identified the quality of the references obtained from the Internet. However, most students $(n=8,61.54 \%)$ did not know the sites providing quality reference sources. Additionally, 53.85\% students did not use online reference sources subscribed by the university. This data showed that the majority of students did not have good knowledge to choose good reference sources from the Internet.

Table 2. Perception toward Applications and Reference Source

\begin{tabular}{|c|c|c|c|c|c|}
\hline Statement about Applications & $\begin{array}{l}\text { Strongly } \\
\text { Disagree }\end{array}$ & Disagree & $\begin{array}{l}\text { Somewhat } \\
\text { Disagree }\end{array}$ & Agree & $\begin{array}{l}\text { Strongly } \\
\text { Agree }\end{array}$ \\
\hline $\begin{array}{l}\text { A computer is the main } \\
\text { hardware in doing course } \\
\begin{array}{l}\text { assignments and research } \\
\text { projects. }\end{array}\end{array}$ & & & 1 & 2 & 10 \\
\hline $\begin{array}{l}\text { Microsoft Office Word is the } \\
\text { main software in doing course } \\
\text { assignments and research } \\
\text { projects. }\end{array}$ & & & 1 & 1 & 11 \\
\hline In writing papers or course & & 1 & 3 & 5 & 4 \\
\hline
\end{tabular}




\begin{tabular}{|c|c|c|c|c|c|}
\hline $\begin{array}{l}\text { assignments, the Heading, } \\
\text { Caption, and Citation menus are } \\
\text { necessary. }\end{array}$ & & & & & \\
\hline $\begin{array}{lll}\text { Statement } & \text { about } & \text { Reference } \\
\text { Sources } & & \end{array}$ & $\begin{array}{l}\text { Strongly } \\
\text { Disagree }\end{array}$ & Disagree & $\begin{array}{l}\text { Somewhat } \\
\text { Disagree }\end{array}$ & Agree & $\begin{array}{l}\text { Strongly } \\
\text { Agree }\end{array}$ \\
\hline $\begin{array}{l}\text { It is easier to obtain references } \\
\text { from local libraries in doing } \\
\text { course assignments. }\end{array}$ & & 1 & 7 & 4 & 1 \\
\hline $\begin{array}{l}\text { Reference sources available in } \\
\text { local libraries have sufficient } \\
\text { quality. }\end{array}$ & & 2 & 7 & 3 & 1 \\
\hline $\begin{array}{l}\text { Reference sources on the Internet } \\
\text { are have better quality, but I do } \\
\text { not know where (the sites) to } \\
\text { obtain them. }\end{array}$ & & & 3 & 8 & 2 \\
\hline
\end{tabular}

Students were presented with statements related to the use of applications and reference sources in the form of a Likert scale to identify whether they had a mature perception of technological literacy. Based on Table 2, it can be seen that $76.92 \%$ of students strongly agreed or had built a strong opinion that computers were the main hardware for doing research assignments. As many as $84.62 \%$ students also strongly agreed that Microsoft Office Word was the main software for doing research assignments. However, the student statement showed a weak perception in utilizing Microsoft Office tools, such as Heading, Caption, and Citation features. This data showed that even though students were users of computers and Microsoft Office Word, their skills in using Microsoft Office tools were still low.

The students also responded to statements about reference sources. Student perceptions indicated that they $(n=7,53.85 \%)$ somewhat disagreed that reference sources for course assignments were easier to obtain from local libraries. This statement is in line with their previous acknowledgment which said that they were used to use sources from the Internet. Student perceptions also showed that they $(n=7,53.85 \%)$ somewhat disagreed that the reference sources in the local library were of sufficient quality. This is supported by a strong opinion that according to the students $(n=8,61.54 \%)$ there were more quality reference sources on the Internet, but they did not know the sites to obtain it. This data indicated that students were not fixated on local libraries, yet they did not have sufficient knowledge to obtain quality reference sources from the Internet.

The survey results showed a phenomenon similar to other studies, such as students who were poorly trained in operating software so that training was needed (John H Heinrichs \& Lim, 2003) and students were not careful and selective in choosing reference sources (Kankam, 2017). Therefore, this action research would benefit students to improve their knowledge and skill in operating Microsoft Office tools and to be skilled and selective in utilizing good quality online reference sources. 


\subsection{Technology Literacy Critical Evaluation}

Referring to the very urgent aspects to be known and mastered by the students based on the pre-action surveys, the critical actions resulted consisted of seven main steps. Throughout the critical actions, there were also many steps that were taken in response to student activities that really needed to be addressed based on their needs. At that time, observations and reflections were carried out. The following are the seven critical action steps to improve students' technology literacy.

\section{Step 1: Motivating the Students and Gain Their Attention}

The results of the pre-action survey showed that the students did not use the features available in Microsoft Office Word, which could ease them to create a list of contents, tables, and images. They heard of a feature to automate it, but they ignored it and never tried to learn it. Therefore, their perceptions had to be changed so they want to understand the importance of using Microsoft Office tools to facilitate their academic work. To attract their interest and attention, several research reports, seminar papers, journal articles, and academic guidebooks from the university were presented. The documents shown were in the .docx and .pdf file formats. The documents were created using the Heading and Caption features, easing for the readers to go to a certain subtitle or chapter. The students were also shown how to update page numbers when changes in writing content occurred, and also how easy it was to create a list of contents, tables, and images automatically.

The survey results also showed that students did not use the Reference Manager application and even preferred to use local reference sources in their course assignments without taking into account the quality of the local sources. Some student's bachelor's theses were also shown, in which the topic of research had not been expanded so that they had not had a state-of-the-art in the research topics. To gain their attention, they viewed several online journals subscribed by the university, which could be downloaded through the university's Internet network. Using the online journals, they saw the important parts where the authors showed the state-of-the-art in their research so that their journals had novelty. They were told that novelty in writing could only be done through 'academic hospitality' by reading relevant previous journal articles and it could not be done only by reading sources available in the local library. They were also shown how to find references online and easily store reference sources using the Reference Manager application and use them easily when they were cited. Up until that time, the students wrote references manually until they realized that there was an easier way to do that.

The students agreed that they had to change their habits in operating Microsoft Office Word and use the Reference Manager application for each of their academic tasks. Using examples of online journals and e-books, the researchers and the students discussed that professional writers or researchers appeared to always use Microsoft Office tools properly. Students also began to ask about how to set up headings in Microsoft Office Word, use Caption, use the Reference Manager, and what journal sites are subscribed by the university. 
Step 2: Summary of Critical Evaluation Process and Definitions

The students were presented with a variety of information introducing that they had missed much of the basic knowledge and skills in information literacy. The information was delivered through presentations using PowerPoint. Information literacy networks to support a variety of academic tasks were presented using the iMindMap application. The students were informed that the American Library Association (ALA) maintains five standards for information literacy competency required by students in higher education (ALA, 2005; Emmett \& Emde, 2007; John H. Heinrichs \& Lim, 2009) as follows.

Table 3. Five Standards of Information Literacy Competency

\begin{tabular}{|c|c|}
\hline Skill Category & Proficiency Requirements \\
\hline Formatting content & $\begin{array}{l}\text { - Create custom styles for text, tables, and lists } \\
\text { - Create and modify diagrams and charts using data } \\
\text { - } \text { from other sources } \\
\text { - Fontrol pagination } \\
\text { - layout features } \\
\text { - Insert and modify objects }\end{array}$ \\
\hline Organizing content & $\begin{array}{l}\text { - Merge letters and labels with other data sources } \\
\text { - } \text { Modify table formats } \\
\text { - } \text { Perform calculations in tables } \\
\text { - Structure documents using XML } \\
\text { - Summarize and navigate document content using } \\
\text { automated tools }\end{array}$ \\
\hline $\begin{array}{l}\text { Formatting } \\
\text { documents }\end{array}$ & $\begin{array}{l}\text { - Create and manage master documents and } \\
\text { subdocuments } \\
\text { - Create and modify forms, document background, and } \\
\text { document indexes and tables } \\
\text { - Insert and modify endnotes, footnotes, captions, and } \\
\text { cross-references }\end{array}$ \\
\hline Collaborating & $\begin{array}{l}\text { - Attach digital signatures to documents } \\
\text { - Manage document versions } \\
\text { - Modify track changes options } \\
\text { - Protect and restrict forms and documents } \\
\text { - Publish and edit Web documents }\end{array}$ \\
\hline Customizing & $\begin{array}{l}\text { - } \text { Modify Microsoft Word default settings } \\
\text { - Create, edit, and run macros } \\
\text { - Customize menus and toolbars }\end{array}$ \\
\hline
\end{tabular}

The students became aware that they did not master many of the five skills that many of the information literacy competency standards including finding and using reputable online reference sources. Therefore, the students were given the Skills Evaluation Checklist in operating Microsoft Office Word and using 
Reference Manager, which showed crucial stages to change their skills with learning activities that prioritize direct practice.

Step 3: Applying the Process to the Supporting Applications

Referring to the Skills Evaluation Checklist, the students were guided by a collaborative team to operate computers using Microsoft Office Word. Of the five skill categories in using Microsoft Office Word, the most sought after by students was the category of formatting content and documents. The students were interested in the category because they saw the examples given previously about Heading and Caption features, so they wanted to immediately practice it. The collaboration team reviewed step by step the practices carried out by the students such as setting the Style, Caption, and produced a list of contents automatically. Initially, the students were guided by a collaboration team and then they sought information on their own via the Internet to practice the five skills according to their respective learning speeds. Students who were rather slower in learning the skill categories were intensely guided by the collaboration team.

The students were then introduced to the Reference Manager application ranging from freeware such as Mendeley to paid ones such as EndNote. They were also informed that Microsoft Office Word also had features to Insert Citation. The students also analyzed the various Reference Manager applications and they decided to download and install the free application, Mendeley. They were given an example on how a reference source is entered manually into Mendeley and also how reference sources are entered automatically. To begin this practice, examples were given on how to include reference sources from national journal databases, and from university journals based on Open Journal Systems (OJS) through the How to Cite Item menu. The students practiced inputting various references to the Mendeley. During this process, it was seen that the students expressed joy because they could easily and quickly input reference sources automatically. Students also practiced to use the references that had been inputted into the Mendeley as a quote in the article and tried to convert them into a variety of citation styles, such as APA, Vancouver, Chicago, and other styles.

Step 4: Browsing and Sharing Work

The students' skills in operating Microsoft Office Word and using the Reference Manager showed significant improvements. However, the crucial aspect that had not changed was how they chose quality sources from the Internet. For this process, they were given individual assignments to browse the Internet looking for reference sources based on the topics that they received in several meetings. They were offered general topics about technology in music education. Then, they chose a more specific topic for research project according to their own interests.

Finding and selecting reference sources on the Internet were not an easy task and it took time. It was observed that the students used Google search engine to find appropriate reference sources for their research project. All of the students 
used the national language in their search for reference sources. Every reference they deemed relevant was downloaded. All of the references in the national language were free and easy to obtain. Conversations with the students during the process were only about the availability of topics relevant to their research project. Repeatedly, they missed the essential discussion about the quality of the reference sources they obtained.

The results of their work were then presented and discussed in the classroom. The website sources and the quality of the contents were evaluated. The majority of the students obtained references based on the Google search engine results. They were not selective about the source as they only took what the search engine had displayed. This meant that they had not known good reference provider websites. They only took references from various websites without knowing what kind of website they were taking from. Moreover, the students only took references in the national language and none of them in an international language. They commented that the references in the national language were easier to find and to understand, whereas references in the international language were difficult to find and to understand. Therefore, the students had not yet considered the quality of the reference sources and they had not yet think globally.

\section{Step 5: Introduction of Online Reference Sources}

Initiating this step, the students were made to compare the reference sources that they had obtained from the Internet with selected online reference sources in the national and international languages. The students were told that the reference sources were in the national journal database accredited by the Ministry of Research, Technology, and Higher Education. The students analyzed several articles and compared them with the articles that they had found. They realized that there were significant differences such as in care for spelling, the way the theoretical framework was built, the way data were interpreted, and the way the discussion was delivered. The references cited by the authors of the articles were nationally accredited and internationally reputable. There were only a small number of books cited and about $80 \%$ of the articles used journal references. All of the articles also showed significant novelty in their topics.

The students were also shown that not all writers think well and academically truthful, and that journal article writers had various skills. This was proven by showing the results of plagiarism screening of the manuscripts sent to the university journal. They were informed that the university had subscribed a plagiarism checker engine named Turnitin so that they could see examples of good and bad journal articles. The students started to show care in choosing reference sources and they started to be more careful in writing so that they were not categorized as unethical writers. Their classroom discussions and comments had built an opinion to shift to using trusted and reputable sources. A question emerged from the students: "We found many sources that issued journals. How do we differentiate the good ones? How do where can we get good reference sources?" 
A few national journal database provider sites were given to the students. All articles in the national journals were downloadable for free since all of them are Open Access journals. The students were informed that national journals have been improved in quality by the Ministry of Research, Technology, and Higher Education through the online journal accreditation. After further exploration, the students started to realized that there were ranks one to six (called Sinta 1-6) in categorizing national journals and those were journals indexed by Scopus. The students then asked what Scopus was, and they received explanation that there were reputable international journal indexer sites, ranging from free access such as the Directory of Open Access Journal (DOAJ) to paid sites such as the Web of Science and Scopus. Based on the results of exploration, reputable international journal indexer also had clusters. As an example, Scopus categorized the journals into Quartiles 1-4. This knowledge strengthened the students' understanding that in using references, they had to be very selective since a number of levels of reputation existed. They were also informed that the university had subscribed international journal sites such as Sage, Springer, Taylor \& Francis Online, and Proquest. The students showed high interest in liking for reference sources from those sites. Google Scholar also became a site used by the students to save reference sources automatically into the Mendeley software. Therefore, the students were then given other reputable reference source provider such as ScienceDirect, Wiley Online Library, and Eric. The difficulty faced by the students was that not all of the websites provided open access articles hence they could not download the full articles they had selected. They only could understand a journal article by reading the abstracts unless they were willing to buy the articles.

\section{Step 6: Applying the Action into a Real Project}

The students did their research projects in the field using the skills to obtain good reference sources in writing their research project report. Moreover, their improved skills in using Microsoft Office Word and Reference Manager could help them more in writing their research project report. During the process, each chapter of the report was observed. In a classroom discussion, the students expressed that they had difficulties in finding topics that were relevant to their project and some students were frustrated about reading the references in English so that they often used Google Translate to understand an article. In the discussion, it was concluded that one of the difficulties was searching for reference sources because the topics for the research projects were in the local context and did not use terms commonly found in international journals. Responding to this, the students adjusted their research topics to make them have a more international atmosphere. This process showed that the students became more critical and evaluative of their own writing and the reference sources they used.

The completed research project reports were submitted in hard copy and .docx formats and were examined carefully. Using the .docx files, it was identified that all of the students had used Microsoft Office tools properly such as using the Heading and Caption so that the list of contents, tables, and images were made automatically. They also had used the Mendeley Reference Manager in citing 
references. Several mistakes were still found, for instance in the list of contents in which page numbers were missed. Therefore, they were informed that sometimes some references automatically obtained from the Internet needed to be manually completed in the Reference Manager and crosschecked with the source journals. A satisfying scene was that most students had used more journal articles as their reference source. Additionally, the results of Turnitin plagiarism checker showed that the level of similarity of their paper were: $2 \%$ for one student $(7.69 \%), 4 \%$ for three students $(23.08 \%), 5 \%$ for one student $(7.69 \%)$, $6 \%$ for one student $(7.69 \%), 7 \%$ for two students $(15.38 \%), 9 \%$ for one student $(7.69 \%), 10 \%$ for one student $(7.69 \%), 11 \%$ for one student $(7.69 \%), 12 \%$ for one student $(7.69 \%)$, and $16 \%$ for one student $(7.69 \%)$. This meant that the level of originality of their writing was very well since they were much lower than Turnitin's maximum standard of similarity index of $24 \%$.

Step 7: Publishing the Research Project Results

One of the targets at the beginning of this research was publishing the students' research report so that they could be indexed by reputable international indexer. The purpose was so that the students had pride in their writing and became used to finding quality writings, reputable websites, and paper publishers. A discussion was made and it was agreed that they would publish through Scopus-indexed international conference proceedings. The appropriate conference was selected for the students according to the topics. The students had to prepare and adjust their report paper to the conference paper template. The paper submission results showed that all of the students' articles were accepted and presentable in the conference although not all of them were chosen to be published in a Scopus-indexed publisher. As many as seven papers $(53.85 \%)$ were chosen to be published and indexed by Scopus and eight papers $(61.54 \%)$ were chosen to be published in a national journal. The students showed good attitude toward the results. Their comments showed high optimism as well as represented changes in their thoughts about the importance of participating in more serious and sophisticated academic realm including making use of the supporting technology.

\section{Discussion and Conclusion}

Analysis of the post-action data was conducted. Compared to the student statements in the pre-action survey, the responses to the use of Microsoft Office tools became higher, showed by the number of students who agreed $(n=2$, $15.38 \%)$ and strongly agreed $(n=11,84.62 \%)$. Moreover, the students had felt the real benefits in their research project reports. In an open-ended question in the survey, a student expressed that, "By using the Microsoft Office tools features such as Heading and Caption, they helped in writing a research project report, because when we are going to work on a certain part, it is not necessary to scroll. We only need to look at the Heading." Another student reinforced that "using the Heading, it is tidy, and it helps in revising parts when there is a mistake." These responses indicated that by viewing or applying how to exploit suitable educational technology in instruction the material and how to assimilate pertinent technology to the tuition subject will be more valuable (Keser et al., 2015; So \& Kim, 2009). 
Regarding the use of Reference Manager application, the student responses showed a strong opinion in using Reference Manager application in managing the list of references. This was showed in the number of students who agreed $(n$ $=3,23.1 \%)$ and strongly agreed $(n=10,76.9 \%)$. When asked further about the reason in an open-ended survey, one of the students responded that "the use of Reference Manager can minimize overlooking in inserting reference sources into the reference list." Another student expressed that "references are managed better because a citation will appear in the reference list automatically." Furthermore, the students were asked to choose the main reference sources to support their research project and all of them $(n=13,100 \%)$ indicated with certainty to use international journals. A student expressed the reason, "journals provide new findings from researchers hence they are more actual to use as references." Another student responded that "there is more scientific novelty from journals and they have quality, especially the reputable international journals." These responses gave a major picture of the change of perception and skills that occurred in students in using Microsoft Office tools and using online reference sources. The students realized the importance of finding gaps of research topics which could only be done by reading reputable and recent journals. Through the state-of -the-art review, the students found out that the topics of their research would offer or propose new perspectives on a topic or an idea an area in requirement of further study (Dochy, 2006). In other words, the students knew various credible and reputable online reference sources. They had known which reference sources that were free and paid. In addition, their skills in operating Microsoft Office Word improved. These were changes in technology literacy that represented the need of critical and evaluative thinking (Aydelott, 2007; Simpson, 2010). The changes also strengthened that technology delivers some of the equipment and progressions that can provision educational improvement and generate tension for alteration (Desteklenmesi et al., 2017).

In conclusion, the steps in the critical evaluation utilized of Microsoft Office tools and reputable online reference sources were organized to help students evaluate their skills. Technology and information literacy truly builds critical and evaluative attitude that are very challenging for lecturers and students. The collaboration team and the students faced a fact that even though computer software is easy to use, the applications are easy to obtain, and the Internet is easy to explore, it is not easy to construct a good quality research report or journal article without higher critical and academic thinking. A higher awareness is needed for good technology and information literacy, thus intense and systematic actions and awareness movements are needed.

The whole process of the action research provided a way to answer various questions mentioned at the beginning in order to know why the students only used local library as the stepping stone to do research. The results of the survey showed that the students were not familiar with using online journal sources; hence they used books available in the local library. Do the students know any quality reference sources on the Internet? Data showed that the students did not have sufficient knowledge and skills to determine credible websites; especially they did not have knowledge about journal indexer. The students also did not know about Reference Manager application and the students did not use the 
Microsoft Office tools to simplify the writing of their research reports. The results of the survey also showed that the students' exploration in using the Microsoft Office Word was not comprehensive resulting in many features available in the application were unknown by the students. The results of the critical steps showed that providing information and examples of using Microsoft Office tools, Reference Manager, and online reference sources to change the students' perception improved their understanding about the tools supporting their research projects. The essential change was the students' awareness to be critical and evaluative about technology literacy skills.

This research merely focuses on developing students' critical and evaluative behavior in the elementary school teacher program to possess technology literacy competency, specifically the mastery of Microsoft Office Tools and Reference Manager. In addition, it was discovered another issues to be solved on how students conduct research projects using proper research management after mastering technology literacy.

\section{References}

Akkoyunlu, B., \& Orhan, F. (2003). Bilgisayar ve öğretim teknolojileri eğitimi (BÖTE) bölümü öğrencilerinin bilgisayar kullanma öz yeterlik inancı ile demografik özellikleri arasındaki ilişki [The relationship between computer and self-efficacy belief and demographic characteristics of computer and instructional technology education students]. The Turkish Online Journal of Educational Technology, 2(3), 8693. https://doi.org/10.7884/teke.4506

ALA. (2005). Information literacy competency standards for higher education: The Association of College and Research Libraries (ACRL). https://doi.org/10.1016/b978-184334-065-2.50016-3.

Auberry, K. (2018). Increasing students' ability to identify fake news through information literacy education and content management systems. The Reference Librarian, 59(4), 179-187. https://doi.org/10.1080/02763877.2018.1489935

Aydelott, K. (2007). Using the ACRL Information Literacy Competency Standards for Science and Engineering/Technology to Develop a Modular Critical-ThinkingBased Information Literacy Tutorial. Science \& Technology Libraries, 27(4), 19-42. https://doi.org/10.1300/j122v27n04_03

Bayrak, F., \& Yurdugül, H. (2013). University Students' Computer Literacy Readiness Level in Turkey. Procedia - Social and Behavioral Sciences, 106, 3210-3215. https://doi.org/10.1016/j.sbspro.2013.12.370

Congress, U. (1984). Office of Technology Assessment. The electronic supervisor: New technology, new tensions. Retrieved from https://ota.fas.org/otareports/

Creswell, J. W. (2015). Educational Research: Planning, Conducting, and Evaluating Quantitative and Qualitative Research, Enhanced Pearson eText with Loose-Leaf Version--Access Card Package. United Kingdom: Pearson Education, Inc.

Desteklenmesi, M. G., Yeterliklerinin, T., \& Örnek, K. B. (2017). Supporting the Professional Development of Early Childhood Teachers in Head Start: A Case of Acquiring Technology Proficiency1 Head Start Programı Erken Çocukluk Dönemi Öğretmenlerinin. Elementary Education Online, 16(4), 1829-1849. https://doi.org/10.17051/ilkonline.2017.342996

Dochy, F. (2006). A guide for writing scholarly articles or reviews for the Educational Research Review. Educational Research Review, 4, 1-2. 
Emmett, A., \& Emde, J. (2007). Assessing information literacy skills using the ACRL standards as a guide. Reference Services Review, 35(2), 210-229. https://doi.org/10.1108/00907320710749146

Gullikson, S. (2006). Faculty perceptions of ACRL's information literacy competency standards for higher education. The Journal of Academic Librarianship, 32(6), 583592. https://doi.org/10.1016/j.acalib.2006.06.001

Heath, P., \& Bell, N. (2006). The Changing World of Home Technology: A Microsoft Case Study. The Information Society, 22(4), 251-259. https://doi.org/10.1080/01972240600791390

Heil, D. (2005). The internet and student research: Teaching critical evaluation skills. Teacher Librarian, 33(2), 26.

Heinrichs, J. H., \& Lim, J. S. (2003). Integrating web-based data mining tools with business models for knowledge management. Decision Support Systems, 35(1), 103-112. https:/ / doi.org/10.1016/s0167-9236(02)00098-2

Heinrichs, J. H., \& Lim, J. S. (2009). Information Literacy and Office Tool Competencies: A Benchmark Study. Journal of Education for Business, 85(3), 153-164. https://doi.org/10.1080/08832320903252371

Iannuzzi, P. (2000). Information literacy competency standards for higher education. $\begin{array}{llll}\text { Community } \& \text { Junior College Libraries, } & 9(4), \quad 63-67 .\end{array}$ https://doi.org/10.1300/j107v09n04_09

Jaipal, K., \& Figg, C. (2011). Collaborative action research approaches promoting professional development for elementary school teachers. Educational Action Research, 19(1), 59-72. https://doi.org/10.1080/09650792.2011.547688

Kankam, P. K. (2017). Evaluation of Internet Information Sources by High School Students in Ghana. International Information \& Library Review, 50(2), 88-93. https://doi.org/10.1080/10572317.2017.1366201

Keser, H., Yılmaz, F. G. K., \& Yılmaz, R. (2015). TPACK Competencies and Technology Integration Self-Efficacy Perceptions of Pre-Service Teachers. Illköğretim Online, 14(4), 1193-1207. https://doi.org/10.17051/io.2015.65067

Klassen, D. (1983). Computer Literacy Revisited. AEDS Journal, 17(1-2), 41-48. doi:https://doi.org/10.1080/00011037.1983.11008358

Leeman, Y., van Koeven, E., \& Schaafsma, F. (2018). Inter-professional collaboration in action research. Educational Action Research, 26(1), 9-24. https://doi.org/10.1080/09650792.2017.1301827

Mackey, T. P., \& Jacobson, T. E. (2005). Information Literacy: A Collaborative Endeavor. College Teaching, 53(4), 140-144. https:// doi.org/10.3200/ctch.53.4.140-144

McCoy, R. W. (2002). Computer competencies for the 21st century information systems educator. Information Technology, Learning, and Performance Journal, 19(2), 101-123. Retrieved from https://ci.nii.ac.jp/naid/20000818599/

Özceylan, E., Kalayci, C. B., Güngör, A., \& Gupta, S. M. (2018). Disassembly line balancing problem: a review of the state of the art and future directions. International Journal of Production Research, 1-23. https://doi.org/10.1080/00207543.2018.1428775

Pask, J. M., \& Saunders, E. S. (2004). Differentiating information skills and computer skills: A factor analytic approach. portal: Libraries and the Academy, 4(1), 61-73. https://doi.org/10.1353/pla.2004.0018

Quinn, A., \& Fitch, D. (2014). A conceptual framework for contextualizing information technology competencies. Journal of Technology in Human Services, 32(1-2), 133148. https://doi.org/10.1080/15228835.2013.860367 
Randhawa, B. S., \& Hunt, D. (1984). Computers and computer literacy in contemporary psychological, socio-economic and educational context. AEDS Journal, 17(3), 113. https:// doi.org/10.1080/00011037.1984.11008365

Reinoehl, R., \& Hanna, T. (1990). Defining computer literacy in human services. Computers in Human Services, 6(1-3), 3-20. https://doi.org/10.1300/j407v06n01_02

Robinson, L. H., \& Thoms, K. J. (2001). A Longitudinal Study of College Student Computer Knowledge. Journal of Computer Information Systems, 42(1), 9-12. https:// doi.org/10.1080/08874417.2001.11647032

Rochester, J. B., \& Rochester, J. (1991). Computers for people: concepts and applications. Irwin Professional Publishing.

Santos, G. M. M. C., Ramos, E. M. C. P. S. L., Escola, J., \& Reis, M. J. C. S. (2019). ICT Literacy and School Performance. TOJET: The Turkish Online Journal of Educational Technology, 18(2), 19-39.

Simpson, A. (2010). Integrating technology with literacy: using teacher-guided collaborative online learning to encourage critical thinking. ALT-J, 18(2), 119-131. https://doi.org/10.1080/09687769.2010.492846

So, H.-J., \& Kim, B. (2009). Learning about problem based learning: Student teachers integrating technology, pedagogy and content knowledge. Australasian Journal of educational technology, 25(1), 101-116. https://doi.org/10.14742/ajet.1183 